\title{
ANALISIS HUBUNGAN CARING PERAWAT DENGAN KEPUASAN PASIEN DI INSTALASI GAWAT DARURAT RUMAH SAKIT UMUM DR. DORIS SYLVANUS PALANGKA RAYA TAHUN 2019
}

\author{
Analysis Of Caring Personnel Relationship With Patient Satisfaction In Emergency \\ Installation Of Dr. Doris Sylvanus Palangka Raya In 2019
}

\section{Eva Prilelli Baringbing ${ }^{*}$}

*IDosen Prodi Kesehatan Masyarakat, STIKES Eka Harap, Palangka Raya, Kalimantan

Tengah, Indonesia

*email: Evaprilelli.april96@gmail.com

Kata Kunci:

Caring Perawat

Kepuasan Pasien

\section{Keywords:}

Caring Nurses

Patient Satisfaction

\begin{abstract}
Abstrak
Mutu pelayanan keperawatan sebagai indikator kualitas pelayanan kesehatan merupakan faktor penentu citra institusi pelayanan kesehatan di mata masyarakat. Sehingga pelayanan keperawatan prima harus diwujudkan untuk mendukung tersedianya pelayanan kesehatan yang berkualitas dan salah satu indikator mutu layanan keperawatan adalah kepuasan pasien dan caring perawat menjadi jaminan layanan perawatan tersebut bermutu. Di Instalasi Gawat Darurat Rumah Sakit Umum Dr. Doris Sylvanus masih ditemukan, perawat kurang informative, dan perawat jarang memberikan penjelasan kepada sebelum melakukan tindakan keperawatan, perawat kurang terampil menangani pasien, dan kurangnya respon cepat tanggap perawat dalam menangani keluhan pasien, perawat kurang memperhatikan pasiennya, kurang ramah. Sehingga pasien dan keluarga pasien memberikan penilaian kurang baik.Menggunakan desain penelitian cross sectional dengan teknik pengambilan sampel aacidental sampling.Responden penelitian berjumlah 93 responden merupakan pasien di IGD Rumah Sakit Umum Dr. Doris Sylvanus. Analisis bivariat yang digunakan analisis chi square. Menunjukkan bahwa caring perawat dengan kepuasaan pasien ( $p$-value 0,000 ), adanya hubungan dengan kepuasan pasien.
\end{abstract}

\begin{abstract}
Nursing sevices quality as an indicator of health sevice quality is a determining factor for the image of health sevice institutions in the public. Therefor,excellent nursing services should be realized in order do support the availability of quality health sevices and one of the indicators of nursing service quality is patient satisfication, and nursing caring attitude as guarantees the quality of the nursing sevices.In the Emergency Room Installation, of dr. Doris Sylvanus Hospital still found nurses who were not informative, and nurses rarely explained to patients before taking nursing action, nurses did not want to accept patient coverage, and were quick to respond to nurses in helping patients, nurses did not pay attention to their patients, were not friendly. Patients and their families give poor ratings for the nurses.This study used a cross-sectional research design used an accidental sampling technique. Respondents of the trial study were 93 respondents representing patients at the emergency room at dr. Doris Sylvanus Hospital. Bivariate analysis that used chi square analysis. The result shown that there nursing nurses with patient satisfaction ( $p$-value 0.000), the relationship with patient satisfaction.
\end{abstract}

\section{PENDAHULUAN}

Pelayanan kesehatan yang berkualitas adalah merupakan hak setiap pasien. Hal ini memacu para penyelenggara pelayanan kesehatan termasuk rumah sakit untuk secara serius berupaya meningkatkan mutu pelayanan yang diberikan. Sekarang adalah zaman bahwa semboyan pasien atau konsumen adalah raja, ini sudah benar-benar harus diwujudkan. Saat ini merupakan masa keunggulan konsumen termasuk kesehatan harus berorientasi pada kepuasan pasien atau konsumen. Aspek-aspek kepuasan pasien terdiri dari pelayanan medis, informasi, makanan, fasilitas akomodasi, lingkungan, pelayanan keperawatan, 
dan jadwal visit ke pasien (Gadalean, Chepte, \& Constantin, 20II).

Era globalisasi yang sedang dan akan kita hadapi di bidang kesehatan menimbulkan harapan akan peluang meningkatnya pelayanan kesehatan. Terbukanya pasar bebas memberikan pengaruh yang penting dalam meningkatkan kompetisi di sektor kesehatan. Persaingan antar rumah sakit memberikan pengaruh dalam manajemen rumah sakit baik milik pemerintah, swasta dan asing dengan tujuan akhir adalah untuk meningkatkan pelayanan. Tuntutan masyarakat akan pelayanan kesehatan yang memadai semakin meningkat turut memberikan warna di era globalisasi dan memacu rumah sakit untuk memberikan layanan terbaiknya agar tidak dimarginalkan oleh masyarakat. Setelah pasien pulang dari rumah sakit mereka akan mengingat kembali pengalaman mereka selama dirawat di rumah sakit, bila mereka merasa puas akan pelayanan keperawatanmaka mereka akan kembali berobat kerumah sakit tersebut ketika mereka membutuhkan perawatan (Otani, Kurz, Barney, \& Steven, 2004).

Berdasarkan hasil Observasi 10 pasien yang telah dilakukan pada tanggal 20 November 2018 di Instalasi Gawat Darurat Rumah Sakit Umum dr. Doris Sylvanus ditemukan, perawat kurang informative, dan perawat jarang memberikan penjelasan kepada pasien sebelum melakukan tindakan keperawatan, perawat kurang terampil menangani pasien, dan kurangnya respon cepat tanggap perawat dalam menangani keluhan pasien, perawat kurang memperhatikan pasiennya, kurang ramah. Sehingga pasien dan keluarga pasien memberikan penilaian kurang baik.

Kondisi seperti ini jika berlangsung dalam jangka lama akan menurunkan kualitas pelayanan di Rumah Sakit Umum dr. Doris Sylvanus Palangka Raya. Penurunan kerja perawat di Rumah Sakit Umum dr. Doris Sylvanus Palangka Raya akan menimbulkan berbagai masalah yaitu didapat dari komite keperawatan bahwa masih adanya keluhan pasien, dan keluhan dari keluarga pasien tentang ketidakpuasan pelayanan yang di peroleh dari perawat di IGD Rumah Sakit Umum dr. Doris Sylvanus Palangka Raya.

Mengingat pentingnya masalah tersebut, maka peneliti tertarik untuk melakukan penelitian ini dengan judul Analisis hubungan antara perilaku caring perawat dengan kepuasan pasien di Instalasi Gawat Darurat Rumah Sakit Umum dr. Doris Sylvanus Palangka Raya Tahun 2019.

\section{METODOLOGI}

\section{Jenis Penelitian}

Jenis penelitian ini menggunakan penelitian survei yang bersifat analitik yaitu mengetahui analisis hubungan caring perawat dengan kepuasan pasien di Instalasi Gawat Darurat Rumah Sakit Umum dr. Doris Sylvanus Palangka Raya Tahun 2019 dengan pendekatan "cross sectional" dimana data yang menyangkut variabel bebas atau resiko dan variabel terikat atau akibat, akan di kumpulkan dalam waktu yang bersamaan (Notoadmodjo,20l0).

\section{Lokasi dan Waktu Penelitian}

Lokasi penelitian di Instalasi Gawat Darurat di Instalasi Gawat Darurat Rumah Sakit Umum dr. Doris Sylvanus Palangka Raya Jl. Tambun Bungai No.04, Langkai, Kec. Pahandut, Kota Palangka Raya, Kalimantan Tengah 73III. Waktu penelitian dilaksanakan pada bulan Februari-Mei 2019.

\section{Populasi dan Sampel}

\section{Populasi Penelitian}

Populasi dalam penelitian ini adalah pasien yang berobat di Instalasi Gawat Darurat di Instalasi Gawat Darurat Rumah Sakit Umum dr. Doris Sylvanus Palangka Raya. Pada tahun 2018 pasien yang datang ke Instalasi Gawat Darurat di Instalasi Gawat Darurat Rumah Sakit Umum dr. Doris Sylvanus Palangka Raya sebanyak 15.173 orang pasien. Jika di rata-ratakan jumlah pasien tiap bulan 
sekitar I.264 orang pasien, dan rata-rata pasien perhari adalah sekitar $4 \mathrm{I}$ orang pasien.

\section{Sampel Penelitian}

Sampel dalam penelitian ini adalah pasien yang berobat ke IGD di Instalasi Gawat Darurat Rumah Sakit Umum dr. Doris Sylvanus Palangka Raya. Teknik pengambilan sampel yang di gunakan dalam penelitian ini adalah accidental sampling, dimana sampel di ambil berdasarkan kejadian kebetulan, yaitu siapa saja yang dianggap tepat dan secara kebetulan bertemu peneliti dan di jadikan sampel.

Kriteria inklusi responden meliputi :

I. Pasien atau keluarga pasien yang bersedia sebagai responden

2. Pasien atau keluarga pasien yang dapat berkomunikasi dengan baik

3. Pasien yang akan di rawat inap

Adapun kriteria ekslusi meliputi :

I. Pasien atau keluarga pasien yang tidak bersedia sebagai responden

2. Pasien yang mengalami kegawatdaruratan yang nyawanya terancam (Code Blue)

Cara pengambilan sampel menggunakan rumus Slovin dengan data kepercayaan $90 \%(\alpha=0,1)$ :

$$
n=\frac{N}{1+N e^{2}}
$$

Jadi, jumlah sampel dalam penelitian ini adalah 93 orang pasien.

\section{Metode Analisis Data}

Analisi dalam penelitian ini berupa analisis data univariat dan data bivariat.

\section{Analisis data Univariat}

Analisis univariat dilakukan untuk mengetahui gambaran distribusi frekuensi masing-masing variabel, baik variabel independen yaitu caring maupun variabel dependen (kepuasan pasien).Keseluruhan data yang ada dalam kuesioner diolah dan disajikan dalam bentuk tabel distribusi frekuensi.
Analisis data bivariat dilakukan untuk melihat apakah ada hubungan yang bermakna antara variabel independen yaitu caring perawat dengan variabel dependen (kepuasan pasien). Pada analisis ini digunakan uji chi-square.

\section{HASIL DAN PEMBAHASAN}

\section{HASIL}

\section{Hasil Analisis Univariat}

Tabel I

\begin{tabular}{|c|c|c|c|}
\hline No. & Jenis kelamin & Frekuensi & Persentase \\
\hline 1. & Laki-laki & 54 oranng & $58 \%$ \\
\hline 2. & Perempuan & 39 orann & $42 \%$ \\
\hline & Total & 93 0rang & $100 \%$ \\
\hline
\end{tabular}

Berdasarkan tabel I dapat dilihat bahwa mayoritas jenis kelamin pasien yang berkunjung ke IGD di Instalasi Gawat Darurat Rumah Sakit Umum dr. Doris Sylvanus Palangka Raya adalah pasien laki-laki sebanyak 54 orang (58 \%) dan pasien perempuan yang berkunjung adalah sebanyak 39 orang.

\section{Tabel 2}

\begin{tabular}{|c|c|c|c|}
\hline No. & Umur & Frekuensi & Persentase \\
\hline 1. & $<20$ tahun & 12 orang & $12,8 \%$ \\
\hline 2. & 20-29 tahun & 17 orang & $18,8 \%$ \\
\hline 3. & 30-39 tahun & 18 orang & $19,4 \%$ \\
\hline 4. & 40-49 tahun & 17 orang & $18,8 \%$ \\
\hline 5. & 50-59 tahun & 16 orang & $17,2 \%$ \\
\hline \multirow[t]{2}{*}{6.} & $>60$ tahun & 13 orang & $13 \%$ \\
\hline & Total & 93 Orang & $100 \%$ \\
\hline
\end{tabular}

Berdasarkan tabel 2 dapat dilihat bahwa mayoritas umur pasien yang berkunjung ke IGD di Rumah Sakit Umum dr. Doris Sylvanus Palangka Raya adalah pasien yang berumur 30-39 tahun sebanyak 18 orang.

\section{Tabel 3}

\begin{tabular}{|l|l|l|l|}
\hline No. & Pendidikan & Frekuensi & Persentase \\
\hline 1. & SD & 10 orang & $10,7 \%$ \\
\hline 2. & SMP & 35 orang & $37,7 \%$ \\
\hline 3. & SMA & 40 orang & $43 \%$ \\
\hline 5. & PT & 8 orang & $8,6 \%$ \\
\hline & Total & 93 Orang & $100 \%$ \\
\hline
\end{tabular}

\section{Analisis data Bivariat}


Berdasarkan tabel 3 dapat dilihat bahwa mayoritas pendidikan pasien yang berkunjung ke IGD di Rumah Sakit Umum dr. Doris Sylvanus Palangka Raya adalah pasien yang memiliki pendidikan SMA yaitu sebanyak 40 orang.

\section{Tabel 4}

\begin{tabular}{|c|c|c|c|}
\hline No. & Kunjungan & Frekluensi & Persentase \\
\hline 1. & Barus sekali & 14 orang & $15,1 \%$ \\
\hline 2. & 2.3 kali & 27 orang & $29 \%$ \\
\hline 3 & 33kali & $520 \mathrm{ranang}$ & $559 \%$ \\
\hline & Total & 930rang & $100 \%$ \\
\hline
\end{tabular}

Berdasarkan tabel 4 dapat dilihat bahwa mayoritas pasien yang berkunjung ke IGD di Rumah Sakit Umum dr. Doris Sylvanus Palangka Raya adalah pasien yang berkunjung lebih dari 3 kali yaitu sebanyak 52 orang.

\section{Tabel 5}

\begin{tabular}{|c|l|l|l|}
\hline No. & Caring perawat & Frekuensi & Persentase \\
\hline 1. & Caring tidak baik & 50 orang & $53,8 \%$ \\
\hline 2. & Caring baik & 43 orang & $46,2 \%$ \\
\hline & Total & 93 Orang & $100 \%$ \\
\hline
\end{tabular}

Berdasarkan tabel 5 dapat dilihat bahwa mayoritas pasien menganggap caring perawat tidak baik IGD di Rumah Sakit Umum dr. Doris Sylvanus Palangka Raya yaitu sebanyak 50 orang.

\section{Tabel 6}

\begin{tabular}{|c|l|l|l|}
\hline No. & Caring perawat & Frekuensi & Persentase \\
\hline 1. & Pasien puas & 48 orang & $51,6 \%$ \\
\hline 2. & Pasien tidak puas & 45 orang & $48,4 \%$ \\
\hline & Total & 93 0rang & $100 \%$ \\
\hline
\end{tabular}

Berdasarkan tabel 6 dapat dilihat bahwa mayoritas pasien puas di IGD di Instalasi Gawat Darurat Rumah Sakit Umum dr. Doris Sylvanus Palangka Raya yaitu sebanyak 48 orang $(5 \mathrm{I}, 6 \%)$.

\section{Hasil Analisis Bivariat}

Tabel 7

\begin{tabular}{|c|c|c|c|c|c|c|c|}
\hline \multirow[t]{3}{*}{ Caring } & \multicolumn{4}{|c|}{ Kepuasan pasien } & \multirow{2}{*}{\multicolumn{2}{|c|}{ Total }} & \multirow[t]{3}{*}{ p-Value } \\
\hline & \multicolumn{2}{|r|}{ Pulas } & \multicolumn{2}{|c|}{ Tidak puas } & & & \\
\hline & n & $\%$ & $n$ & $\%$ & n & $\%$ & \\
\hline Baik & 33 & $35,3 \%$ & 10 & $10,7 \%$ & 43 & $46,3 \%$ & .000 \\
\hline $\begin{array}{l}\text { Kurang } \\
\text { baik }\end{array}$ & 15 & $16,1 \%$ & 35 & $37,6 \%$ & 50 & $53,7 \%$ & \\
\hline TOTAL & 48 & $51,4 \%$ & 57 & $48,9 \%$ & 93 & $100 \%$ & \\
\hline
\end{tabular}

Dari tabel II dapat dilihat bahwa pasien yang puas dengan caring perawat yang baik adalah sebanyak 33 orang $(35,3 \%)$ serta pasien yang tidak puas dengan caring perawat yang baik adalah sebanyak 10 orang (10,7 $\%)$, dan pasien yang merasa puas dengan caring perawat yang kurang baik adalah sebanyak 15 orang $(16,1 \%)$, serta pasien yang merasa tidak puas dengan caring perawat yang kurang baik adalah sebanyak 35 orang (37,6\%).

Hasil analisa untuk mengetahui adanya hubungan antara caring perawat dengan kepuasan pasien di dapat $p$-value .000 sehingga di dapat kesimpulan bahwa adanya hubungan caring perawat dengan kepuasan pasien di Instalasi Gawat Darurat Rumah Sakit Umum dr. Doris Sylvanus Palangka Raya Tahun 2019.

\section{PEMBAHASAN}

Hasil penelitian ini hubungan antara caring perawat dengan kepuasan pasien di Instalasi Gawat Darurat Rumah Sakit Umum dr. Doris Sylvanus Palangka Raya dimana nilai $r=0.000 \quad(p<0,05)$ yang berarti bahwa hipotesa nol ditolak atau dengan kata lain ada hubungan yang signifikan antara caring dengan kepuasan pasien. Hal ini di perkuat oleh hasil penelitian Malini (2009) yang bertujuan mengidentifikasi perilaku caring perawat di RS Dr. Djamil didapati perawat masih kurang ramah dalam melayani pertanyaan dari klien, berperilaku tidak bersahabat dan jarang tersenyum ini berarti masih didapati perawat yang belum menunjukkan perilaku caring dalam memberikan asuhan keperawatan. Begitu juga dengan hasil pengamatan suwardi (2008) terhadap komunikasi terapeutik perawat di RSU Pandan Arang Boyolali yang dijumpai masih ada perawat yang cenderung emosi saat menerima keluhan dari klien, perawat yang hanya duduk-duduk di ruang perawat, 
perawat yang cenderung tidak tahu mengenai kondisi klien, dan perawat kurang memahami keluhan yang dirasakan klien. Ini berarti perilaku caring masih kurang ditunjukkan oleh perawat yang bekerja di rumah sakit. Hasil penelitian ini sejalan dengan penelitian yang dilakukan oleh Andariyani (2009), hubungan antara caring perawat dengan tingkat kepuasan pasien di ruang rawat inap RSUD Tugurejo semarang yang menyatakan bahwa ada hubungan yang bermakna antara caring perawat dengan tingkat kepuasan pasien dengan $P$-value 0,001 dimana sebagian besar perawat dalam memberikan pelayanan (caring) terhadap pasien mayoritas rendah yaitu sebanyak 191 responden (83,8\%).

Hal ini erat kaitannya dengan kondisi di Instalasi Gawat Darurat Rumah Sakit Umum dr. Doris Sylvanus Palangka Raya bahwa pelaksanaan tahapan caring perlu dioptimalkan dalam mencapai kinerja perawat yang baik sehingga kepuasan pasien dapat meningkat, terkhusus dalam memberikan pelayanan keperawatan kepada pasien. Begitu juga halnya dengan pengawasan dan motivasi yang tinggi dari pihak manajerial dalam hal penilaian kinerja, organisasi kerja yang baik, serta sistem reward yang mendukung melalui pengembangan kearah pelatihan dan pendidikan lanjut yang diberikan kepada perawat yang memiliki kinerja yang baik.

\section{KESIMPULAN}

I. Pada dimensi kepuasan pasien mayoritas berada dalam kategori puas (5I,6\%) sebanyak 48 orang dan tidak puas $(48,4 \%)$ sebanyak 45 orang, dari hasil dapat disimpulkan bahwa pasien yang di rawat di Rumah Sakit Umum Bina Kasih telah mendapatkan kepuasan dengan baik.

2. Pada dimensi caring perawat nilai $r=0,000(p<0,05)$ yang berarti bahwa hipotesa nol ditolak ada hubungan yang signifikan antara caring dengan kepuasan pasien.
Berisi Informasi ucapan terima kasih serta penghargaan kepada pihak-pihak yang telah berpartisipasi dalam kegiatan penelitian yang dilakukan. Bisa kepada institusi penyedia anggaran maupun hibah (mencantumkan sumber dan skema hibah yang digunakan), pihak institusi tempat kegiatan penelitian dilakukan, narasumber, organisasi dan unsur masyarakat, serta sivitas akademika yang telah membantu pelaksanaan kegiatan penelitian.

\section{REFERENSI}

I. Andriyani, Heni. 2009. Hubungan Antara Caring Perawat Dengan Tingkat Kepuasan Pasien.

2. Gadalean, I., Chepte, M., \& Constantin, I. (20II). Evaluation of patients satisfaction. Journal of Applied Medical Informatic, 4I-47.

3. Malini, H \& Sartika, D. (2009).Hubungan kecerdasan spiritual dengan perilaku caring perawat di RSMD Jamil Padang. Artikel Ilmiah.

4. Notoatmodjo. S (2010) Metodologi Penelitian, RinekaCipta, Jakarta.

5. Otani, K., Kurz, R.S., Barney, M. \& Steven. 2004. The Impact of Nursing Care and Other Healthcare Attributs on Hospitalized Patient Satisfaction and Behavior Intensions. Journal of Healthcare Management,49 (3).

6. Suwardi. 2008. Hubungan antara Kecerdasan Emosi dengan Kemampuan Komunikasi Terapeutik di RSU Pandan Arang Boyolali. Skripsi. UMS. Surakarta.

\section{UCAPAN TERIMA KASIH}

